\title{
STRUCTURAL PROPERTIES OF SOIL IN MAIZE AND FORAGE GRASS INTERCROPPING UNDER NO-TILLAGE IN THE BRAZILIAN CERRADO
}

\author{
Camila P. Cagna ${ }^{1}$, Zieglenristen K. P. Calábria ${ }^{2 *}$, Osvaldo Guedes Filho ${ }^{1}$, Leandro P. Pacheco ${ }^{3}$, \\ Tonny J. A. da Silva ${ }^{3}$
}

${ }^{2 *}$ Corresponding author. Universidade Federal do Paraná/ Curitiba - PR, Brasil.

E-mail: zcalabria@hotmail.com | ORCID ID: https://orcid.org/0000-0002-5053-8293

\section{KEYWORDS}

aggregate stability index, tensile strength, soil physical quality.

\begin{abstract}
Integration of forage grasses with grain crops, such as maize, allows maintaining soil cover. The objective of this study was to evaluate the tensile strength, friability, and stability of soil aggregates in the maize and forage grass intercropping under no-tillage system. The study used a completely randomized block design with seven treatments and three replications. Undisturbed soil samples were collected in two seasons (2015 and 2016 ) at $0-0.10 \mathrm{~m}$ and $0.10-0.20 \mathrm{~m}$ soil depth. The following properties of soil aggregates were measured: tensile strength (TS), friability (F), gravimetric moisture (GM), weighted mean diameter (WMD), geometric mean diameter (GMD), and aggregate stability index (ASI). The intercropping of maize with Urochloa ruziziensis presented higher WMD and GMD at $0.10-0.20 \mathrm{~m}$ soil depth. Moreover, TS at $0.10-0.20 \mathrm{~m}$ soil depth was lower in maize without intercropping. The effects of the intercropping system on soil aggregates were better detected by aggregate stability than by TS or F. The intercropping of maize and $U$. ruziziensis improved soil aggregation to a higher extent than those systems with other forage grasses.
\end{abstract}

\section{INTRODUCTION}

One of the main challenges of modern agriculture is producing food for a growing world population, which has become more demanding regarding reductions of external inputs and environmental impacts (Pittelkow et al., 2014). The no-tillage (NT) system is a conservative soil management capable of sustaining agricultural production and improve soil and environmental quality. One of its basic premises is maintaining crop residues on the soil surface, protecting natural soils, and recovering the production capacity of conventionally tilled soils (BlancoCanqui \& Ruis, 2018; Garcia et al., 2014).

In the Cerrado, one of the major obstacles to the consolidation of NT system is maintaining soil cover throughout the year. In this region, the climate is characterized by dry winters and high temperatures, which speed up the decomposition of organic matter, reducing permanence of straw in cultivated fields (Pacheco et al., 2017).

The integration of forage grasses to grain crops by intercropping of maize with some forage species allows maintenance of soil cover (Ceccon \& Concenço, 2014). In addition to maize grain production, the integration of forage grasses improves land cover quality and quantity, besides increasing and maintaining organic matter (OM) contents and nutrient recycling for subsequent crops (Lemaire et al., 2014), reducing soil erosion and improving soil physical properties (Silva et al., 2015).

Changes in soil physical structure due to management system can be measured by evaluating soil formation and structural stability (Ferreira et al., 2018). Aggregate stability index (ASI), tensile strength (TS), and friability have been used to assess structural variations by soil management (Tormena et al., 2008a) and are useful indicators of ecosystem recovery (Demenois et al., 2017).

As maize intercropping with forage grasses has been widely practiced, it is essential to evaluate potential changes in soil structure after using these systems. The hypothesis of this study was that the intercropping of maize with forage grasses would improve soil structural quality when compared to maize without intercropping. Therefore, the objective of this study was to evaluate the aggregate stability, friability, and tensile strength of soil aggregates in the maize and forage grass intercropping under no-tillage system, in the Brazilian Cerrado.

\footnotetext{
${ }^{1}$ Universidade Federal do Paraná/ Jandaia do Sul - PR, Brasil.

${ }^{3}$ Universidade Federal de Mato Grosso/ Rondonópolis - MT, Brasil.

Received in: 3-25-2019

Accepted in: 6-6-2019
} 


\section{MATERIAL AND METHODS}

The study was conducted in an experimental area of the Federal University of Mato Grosso (Universidade Federal de Mato Grosso-UFMT), in Rondonópolis, Mato Grosso state, Brazil (16 $28^{\prime} \mathrm{S}$ and $\left.54^{\circ} 38^{\prime} \mathrm{W}\right)$. The study area has been grown under a no-tillage system (NT) since 2014, and the soil was classified as a Red Latosol (Embrapa, 2018). Soil physical properties at 0-0.20 m soil depth showed the following values: clay content $500 \mathrm{~g} \mathrm{~kg}^{-}$ 1; silt content $100 \mathrm{~g} \mathrm{~kg}^{-1}$; sand content $400 \mathrm{~g} \mathrm{~kg}^{-1}$; particle density $2.60 \mathrm{Mg} \mathrm{m}^{-3}$; and organic carbon content $12.06 \mathrm{~g}$ $\mathrm{kg}^{-1}$. The mean annual rainfall in the region is $1800 \mathrm{~mm}$. The local climate is type $A w$ according to the classification of Köppen.

The study was carried out in a completely randomized block design with three replications and seven treatments, as follows: maize + Urochloa brizantha cv. Marandú (UM), maize $+U$. ruziziensis (UR), maize $+U$. humidicola $(\mathrm{UH})$, maize $+U$. decumbens (UD), maize + Panicum maximum cv. Tanzânia (PT), maize $+P$. maximum cv. Mombaça (PM), and maize without intercropping (WI), totaling 21 experimental plots, each plot with an area of $64 \mathrm{~m}^{2}(8 \mathrm{~m} \times 8 \mathrm{~m})$.

Soybean was the first crop used in the study area and was planted in early November 2014. Before the study period, the area was composed of native Cerrado. Maize was sown in February 2015 and 2016, shortly after soybean harvest. Forage grasses were sown broadcast between maize rows in early March 2015 and 2016. Soil correction and fertilization in the cultivated crops were performed according to Boletim 100 (Raij et al., 1997). The sowing schedule and crop protection were defined according to technical recommendations for each crop.

To determine tensile strength (TS) and aggregate stability (AS), undisturbed soil samples were collected at $0-0.10 \mathrm{~m}$ and $0.10-0.20 \mathrm{~m}$ soil depth after forage desiccation in September 2015 and October 2016, and aggregates were manually crushed and dried in a greenhouse. The aggregates were sieved according to the method described in Imhoff et al. (2002). Aggregate size used for TS was between 9.5 and $4.75 \mathrm{~mm}$. Yet, AS was calculated using aggregates retained between 4.75 - and 2.00-mm mesh sieves.

Both TS and AS were measured at the Soil Laboratory of the Federal University of Paraná (Universidade Federal do Paraná-UFPR) at the Campus of Jandaia do Sul. TS was measured using a bench penetrometer with an adapted penetration needle (Imhoff et al., 2002). Aggregate samples were subjected to fracture at a constant speed with five replications of 10 aggregates per sample, totaling 50 aggregates per sample. Soil analyses were performed for the two sampled depths, each containing 21 samples, totaling 2,100 aggregates. Each aggregate was weighed before and after TS measurement. Soil moisture was determined gravimetrically after drying the samples in an oven at $105^{\circ} \mathrm{C}$ for 24 hours.

Tensile strength was calculated according to Dexter \& Kroesbergen (1985):

$$
T S=0.576 \times\left(\frac{P}{D^{2}}\right)
$$

Where:

0.576 is the coefficient of proportionality;

$\mathrm{P}$ is the applied force (in Newton),

$\mathrm{D}$ is the effective diameter (in $\mathrm{mm}$ ).
The effective diameter was calculated according to Watts \& Dexter (1998):

$$
D=D m \times\left(\frac{M}{M o}\right)^{\frac{1}{3}}
$$

Where:

$\mathrm{Dm}$ is the mean aggregate diameter (in $\mathrm{mm}$ );

$\mathrm{M}$ is the aggregate mass (in grams),

Mo is the mean mass in an aggregate population (in grams).

The mean aggregate diameter was considered equal to the mean size of the sieves $[(9.5+4.75) / 2]$ used to select aggregates.

Friability was estimated using the coefficient of variation method proposed by Watts \& Dexter (1998):

$$
F=\frac{\sigma_{Y}}{Y} \pm \frac{\sigma_{Y}}{Y \sqrt{2 n}}
$$

Where:

$\mathrm{F}$ is soil friability;

$\sigma \mathrm{Y}$ is the standard deviation of TS values;

$\mathrm{Y}$ is the mean TS,

$\mathrm{n}$ is the number of replications.

The second term of the equation corresponds to the standard error of the coefficient of variation. Friability was classified as proposed by Imhoff et al. (2002) as follows: non-friable $(<0.10)$, slightly friable $(0.10-0.20)$, friable $(0.20-0.50)$, very friable $(0.50-0.80)$, and mechanically unstable $(>0.80)$.

Aggregate-size distribution was determined by wetsieving. The diameters of sieves were 2.0, 1.0, 0.5, 0.25, and $0.105 \mathrm{~mm}$ (Embrapa, 2017). The sieves were operated for $15 \mathrm{~min}$ at $30 \mathrm{rpm}$ in a vertical motion. The dry weight of the soils retained in each sieve was measured after drying the samples in an oven at $105{ }^{\circ} \mathrm{C}$ for $24 \mathrm{~h}$. AS was determined by measuring the weighted mean diameter (WMD), geometric mean diameter (GMD), and aggregate stability index (ASI) according to Castro Filho et al. (2002).

$$
\begin{aligned}
& \text { WMD }=\sum(x i \cdot y i) \\
& \text { GMD }=\exp \left\{\frac{\sum \text { wiln xi }}{\sum w i}\right\} \\
& \text { ASI (\%) }=\frac{\text { Weight of dry aggregates-w0.25-sand }}{\text { Weight of dry aggregates }-\mathrm{s}}
\end{aligned}
$$

Where:

$\mathrm{xi}$ is the mean size of the aggregate classes (in $\mathrm{mm}$ );

yi is the ratio of each of aggregate size class (in grams) relative to the total sample;

wi is the weight of the aggregates of each class (in grams),

w0.25 is the weight of the aggregates of the class smaller than $0.25 \mathrm{~mm}$. 
Granulometric fractions of clay, silt, and sand were determined by densitometry, according to the method described by Grossman \& Reinsch (2002), to obtain the percentage of sand used for ASI calculations.

Data were subjected to analysis of variance, and the means were compared using the Tukey's test at a level of significance of 5\%. All statistical analyses were performed using SAS software (SAS Institute, 2002).

\section{RESULTS AND DISCUSSION}

\section{Aggregate stability (AS) and soil organic matter (OM)}

No significant differences were observed in WMD, GMD, and ASI among treatments at $0-0.10 \mathrm{~m}$ soil depth, in 2015 (Table 1). At 0.10-0.20 m soil depth, WMD (2.31 $\mathrm{mm}$ ) was higher in treatment UR; however, this value did not differ significantly from those of treatments PT, UH, PM, UM, and UD. GMD was higher $(2.07 \mathrm{~mm})$ in treatment UR but was not significantly different from those of treatments PT, UH, PM, UM, and UD. ASI ranged from $85.03 \%$ to $93.34 \%$. ASI was highest in treatment UR but did not differ significantly from those of treatments UH, PM, UM, and UD (Table 1).

TABLE 1. Mean values of weighted mean diameter (WMD), geometric mean diameter (GMD), aggregate stability index (ASI), and organic matter (OM) content at $0-0.10$ and $0.10-0.20 \mathrm{~m}$ soil depth in the intercropping of maize with forage grasses in Rondonópolis, Mato Grosso, Brazil, 2015.

\begin{tabular}{|c|c|c|c|c|c|c|c|c|}
\hline \multirow{2}{*}{ Treatment } & \multicolumn{4}{|c|}{ 0-0.10 m } & \multicolumn{3}{|c|}{$0.10-0.20 \mathrm{~m}$} & \multirow[b]{2}{*}{ OM (\%) } \\
\hline & WMD & GMD & ASI & OM (\%) & WMD & GMD & ASI & \\
\hline P. maximum cv Tanzânia (PT) & $2.21 \mathrm{a}$ & $1.86 \mathrm{a}$ & $89.99 \mathrm{a}$ & $1.66 \mathrm{a}$ & $2.14 \mathrm{ab}$ & $1.80 \mathrm{ab}$ & $85.39 \mathrm{~b}$ & $1.58 \mathrm{a}$ \\
\hline Maize without intercropping (WI) & $2.15 \mathrm{a}$ & $1.80 \mathrm{a}$ & $88.05 \mathrm{a}$ & $1.64 \mathrm{a}$ & $2.07 \mathrm{~b}$ & $1.67 \mathrm{ab}$ & $85.03 \mathrm{~b}$ & $1.61 \mathrm{a}$ \\
\hline U. humidicola $(\mathrm{UH})$ & $2.14 \mathrm{a}$ & $1.79 \mathrm{a}$ & $86.61 \mathrm{a}$ & $1.58 \mathrm{a}$ & $2.17 \mathrm{ab}$ & $1.83 \mathrm{ab}$ & $88.33 \mathrm{ab}$ & $1.42 \mathrm{a}$ \\
\hline P. maximum cv Mombaça (PM) & $2.21 \mathrm{a}$ & $1.91 \mathrm{a}$ & $90.29 \mathrm{a}$ & $1.62 \mathrm{a}$ & $2.29 \mathrm{a}$ & $2.02 \mathrm{a}$ & $91.70 \mathrm{ab}$ & $1.50 \mathrm{a}$ \\
\hline U. brizantha cv. Marandú (UM) & $2.15 \mathrm{a}$ & $1.78 \mathrm{a}$ & $87.87 \mathrm{a}$ & $1.67 \mathrm{a}$ & $2.24 \mathrm{ab}$ & $1.91 \mathrm{ab}$ & $90.04 \mathrm{ab}$ & $1.40 \mathrm{a}$ \\
\hline U. decumbens (UD) & $2.25 \mathrm{a}$ & $1.94 \mathrm{a}$ & $90.61 \mathrm{a}$ & $1.63 \mathrm{a}$ & $2.23 \mathrm{ab}$ & $1.91 \mathrm{ab}$ & $89.16 \mathrm{ab}$ & $1.55 \mathrm{a}$ \\
\hline U. ruziziensis (UR) & $2.15 \mathrm{a}$ & $1.79 \mathrm{a}$ & $88.50 \mathrm{a}$ & $1.94 \mathrm{a}$ & $2.31 \mathrm{a}$ & $2.07 \mathrm{a}$ & $93.34 \mathrm{a}$ & $2.05 \mathrm{a}$ \\
\hline MSD & 0.20 & 0.32 & 5.91 & 0.68 & 0.19 & 0.30 & 7.58 & 0.73 \\
\hline $\mathrm{CV}$ & 7.62 & 14.55 & 5.78 & 13.61 & 8.62 & 16.32 & 8.62 & 18.28 \\
\hline
\end{tabular}

Means followed by the same lower-case letters compare the treatments at $0.0-0.10 \mathrm{~m}$ and $0.10-0.20 \mathrm{~m}$ soil depth, and they do not differ from each other by the Tukey's test at 5\% probability. MSD, minimum significant difference; CV, coefficient of variation.

Santos et al. (2012) showed that Brachiaria grasses have an extensive and active root system and that the exudation of organic compounds from the roots may contribute to the formation of stable aggregates. However, at $0.0-0.10 \mathrm{~m}$ soil depth, these factors could not differentiate between the intercropping system Brachiaria species and the other treatments, probably due to the short time of experiment installation. On the other hand, at 0.10 $0.20 \mathrm{~m}$ soil depth, the results demonstrate the beneficial effect of intercropping, especially in treatment UR. The analysis of WMD, GMD, and ASI indicates that soil aggregates were formed and stabilized in treatments UR, UM, and PM due to the action of the root system, possibly contributing to the bonding of smaller aggregates to form larger aggregates. Pereira et al. (2010) observed that the higher was WMD and GMD, the greater was the contribution of intercropping for aggregate stabilization.
Brandão \& Silva (2012) observed that the root system of $U$. ruziziensis significantly affected the formation and stabilization of soil aggregates. The results obtained in layer $0.10-0.20 \mathrm{~m}$ soil depth using $U$. ruziziensis were not significantly different from those of the other treatments but presented a higher tendency of forming and stabilizing aggregates among the forage grasses evaluated.

No significant differences were detected in OM among treatments in the first year of cultivation. However, the results suggest an increasing trend in $\mathrm{OM}$ in the intercropping of maize with $U$. ruziziensis, and this increase was observed in the next season. In addition, to the effect of the root system, the increase in OM favors the formation and stabilization of soil aggregates, improving soil structure (Araújo et al., 2013).

No significant difference was noted for WMD in 2016 at $0-0.10 \mathrm{~m}$ soil depth (Table 2). 
TABLE 2. Mean values of weighted mean diameter (WMD), geometric mean diameter (GMD), aggregate stability index (ASI), and organic matter (OM) content at $0-0.10$ and $0.10-0.20 \mathrm{~m}$ soil depth in the intercropping of maize with forage grasses in Rondonópolis, Mato Grosso, Brazil, 2016.

\begin{tabular}{ccccccccc}
\hline \multirow{2}{*}{ Treatment } & \multicolumn{3}{c}{$\mathbf{0 - 0 . 1 0} \mathbf{~ m}$} & \multicolumn{4}{c}{$\mathbf{0 . 1 0}-\mathbf{0 . 2 0} \mathbf{~ m}$} \\
\cline { 2 - 8 } & WMD & GMD & ASI & OM (\%) & WMD & GMD & ASI & OM (\%) \\
\hline P. maximum cv Tanzânia (PT) & $1.92 \mathrm{a}$ & $1.06 \mathrm{ab}$ & $79.82 \mathrm{a}$ & $2.22 \mathrm{ab}$ & $2.33 \mathrm{a}$ & $1.14 \mathrm{a}$ & $85.10 \mathrm{ab}$ & $1.79 \mathrm{a}$ \\
Maize without intercropping (WI) & $1.61 \mathrm{a}$ & $0.99 \mathrm{~b}$ & $69.04 \mathrm{~b}$ & $2.12 \mathrm{ab}$ & $1.90 \mathrm{c}$ & $1.05 \mathrm{~b}$ & $76.57 \mathrm{~b}$ & $1.92 \mathrm{a}$ \\
U. humidicola $(\mathrm{UH})$ & $1.85 \mathrm{a}$ & $1.04 \mathrm{ab}$ & $74.98 \mathrm{ab}$ & $2.20 \mathrm{ab}$ & $2.28 \mathrm{abc}$ & $1.13 \mathrm{ab}$ & $83.54 \mathrm{ab}$ & $1.81 \mathrm{a}$ \\
P. maximum cv Mombaça (PM) & $1.93 \mathrm{a}$ & $1.05 \mathrm{ab}$ & $76.69 \mathrm{ab}$ & $2.22 \mathrm{ab}$ & $2.06 \mathrm{abc}$ & $1.08 \mathrm{ab}$ & $78.09 \mathrm{~b}$ & $1.80 \mathrm{a}$ \\
U. brizantha cv. Marandú (UM) & $2.00 \mathrm{a}$ & $1.07 \mathrm{a}$ & $78.77 \mathrm{a}$ & $2.16 \mathrm{ab}$ & $1.93 \mathrm{bc}$ & $1.06 \mathrm{~b}$ & $77.42 \mathrm{~b}$ & $1.92 \mathrm{a}$ \\
U. decumbens (UD) & $1.87 \mathrm{a}$ & $1.05 \mathrm{ab}$ & $76.99 \mathrm{ab}$ & $2.05 \mathrm{~b}$ & $2.19 \mathrm{abc}$ & $1.11 \mathrm{ab}$ & $82.28 \mathrm{ab}$ & $1.86 \mathrm{a}$ \\
U. ruziziensis (UR) & $1.90 \mathrm{a}$ & $1.05 \mathrm{ab}$ & $78.82 \mathrm{a}$ & $2.45 \mathrm{a}$ & $2.32 \mathrm{ab}$ & $1.14 \mathrm{a}$ & $87.60 \mathrm{a}$ & $1.91 \mathrm{a}$ \\
\hline MSD & 0.4 & 0.09 & 8.7 & 0.33 & 0.40 & 0.08 & 8.82 & 0.57 \\
\hline CV & 17.71 & 6.26 & 9.81 & 7.67 & 17.61 & 7.07 & 10.33 & 10.46 \\
\hline
\end{tabular}

Means followed by same lower-case letters compare the treatments at $0.0-0.10 \mathrm{~m}$ and $0.10-0.20 \mathrm{~m}$ soil depth, and they do not differ from each other by the Tukey's test at $5 \%$ probability. MSD, minimum significant difference; CV, coefficient of variation.

Significant differences were observed in WMD, GMD, and ASI at 0.10-0.20 m soil depth in the year 2016 (Table 2). Wendling et al. (2012) found that GMD and MWD were lower at $0.10-0.20 \mathrm{~m}$ soil depth in a RedYellow Dystrophic Latosol in soils of the Cerrado, Pinus crops, pasture, and direct sowing. However, ASI values were similar to those found in this study $(93 \%, 85 \%, 80 \%$, and $69 \%$, respectively). These authors observed that aggregate size was larger in soils with limited tillage, as in the case of the Cerrado, whereas the original structure of aggregates was lost in soils with more intense tillage.

\section{Tensile strength (TS) and friability (F)}

The mean TS values were not significantly different among treatments at $0-0.10 \mathrm{~m}$ and $0.10-0.20 \mathrm{~m}$ soil depth in 2015 (Table 3). TS varied from 73.71 to $97.11 \mathrm{kPa}$ at
$0-0.10 \mathrm{~m}$ and from 66.13 to $79.89 \mathrm{kPa}$ at $0.10-0.20 \mathrm{~m}$. At 0.10-0.20 m soil depth, TS was lowest in treatment WI $(66.13 \mathrm{kPa})$ and highest in treatment PT $(79.83 \mathrm{kPa})$. The variation in TS at $0-0.10 \mathrm{~m}$ may have been influenced by the direct contact with OM, which can promote both either an increase or decrease in TS. The increase in TS is due to the cementing of OM to the mineral particles of the soil, and the decrease in TS is due to the increase in the number of pores and points of weakness inside the aggregates. In treatment WI, TS at $0-0.10 \mathrm{~m}$ was $92.12 \mathrm{kPa}$, demonstrating that the absence of cover crops promoted soil compaction by the direct contact with rainwater and machinery.

Silva (2018 et al.) obtained similar mean values at 0 $0.10 \mathrm{~m}$ in soils under fallow, millet, and pasture, and corresponding to $74.73,73.81$, and $88.66 \mathrm{kPa}$, respectively.

TABLE 3. Mean values of the tensile strength (TS), friability (F), and moisture (M) at $0-0.10$ and $0.10-0.20 \mathrm{~m}$ soil depth in the intercropping system of maize with forage grasses in Rondonópolis, Mato Grosso, Brazil, 2015.

\begin{tabular}{|c|c|c|c|c|c|c|}
\hline \multirow{2}{*}{ Treatment } & \multicolumn{3}{|c|}{ 0-0.10 m } & \multicolumn{3}{|c|}{$0.10-0.20 \mathrm{~m}$} \\
\hline & TS & $\mathbf{F}$ & M & TS & $\mathbf{F}$ & $\mathbf{M}$ \\
\hline P. maximum cv Tanzânia (PT) & $73.71 \mathrm{a}$ & $0.89 \mathrm{a}$ & $0.023 \mathrm{a}$ & $79.83 \mathrm{a}$ & $0.86 \mathrm{a}$ & $0.016 \mathrm{a}$ \\
\hline Maize without intercropping (WI) & $92.12 \mathrm{a}$ & $0.76 \mathrm{a}$ & $0.018 \mathrm{a}$ & $66.13 \mathrm{a}$ & $0.98 \mathrm{a}$ & $0.017 \mathrm{a}$ \\
\hline U. humidicola $(\mathrm{UH})$ & $89.47 \mathrm{a}$ & $0.90 \mathrm{a}$ & $0.016 \mathrm{a}$ & $68.55 \mathrm{a}$ & $0.86 \mathrm{a}$ & $0.016 \mathrm{a}$ \\
\hline P. maximum cv Mombaça (PM) & $93.97 \mathrm{a}$ & $0.72 \mathrm{a}$ & $0.016 \mathrm{a}$ & $83.34 \mathrm{a}$ & $0.79 \mathrm{a}$ & $0.016 \mathrm{a}$ \\
\hline U. brizantha cv. Marandú (UM) & $97.11 \mathrm{a}$ & $0.80 \mathrm{a}$ & $0.016 \mathrm{a}$ & $71.84 \mathrm{a}$ & $0.94 \mathrm{a}$ & $0.018 \mathrm{a}$ \\
\hline U. decumbens (UD) & $92.45 \mathrm{a}$ & $0.86 \mathrm{a}$ & $0.015 \mathrm{a}$ & $77.90 \mathrm{a}$ & $0.86 \mathrm{a}$ & $0.017 \mathrm{a}$ \\
\hline U. ruziziensis (UR) & $84.57 \mathrm{a}$ & $0.69 \mathrm{a}$ & $0.016 \mathrm{a}$ & $79.10 \mathrm{a}$ & $0.79 \mathrm{a}$ & $0.017 \mathrm{a}$ \\
\hline MSD & 31.85 & 0.29 & 0.013 & 27.43 & 0.29 & 0.003 \\
\hline $\mathrm{CV}$ & 32.4 & 33.34 & 71.87 & 33.33 & 30.19 & 15.97 \\
\hline
\end{tabular}

Means followed by the same lower-case letters compare the treatments at $0.0-0.10 \mathrm{~m}$ and $0.10-0.20 \mathrm{~m}$ soil depth, and they do not differ from each other by the Tukey's test at $5 \%$ probability. MSD, minimum significant difference; $\mathrm{CV}$, coefficient of variation.

The mean values of TS at $0.10-0.20 \mathrm{~m}$ soil depth were lower than those found by Reis et al. (2014) in a coal mining area at $0.10-0.15 \mathrm{~m}$ in soils cultivated with Bermuda grass, Tanzânia grass, and cover crops, corresponding to $88.35,125.92$, and $98.43 \mathrm{kPa}$, respectively. The lower values found in the present study were caused by the shortterm effect (i.e., two harvests) of forage grasses. Nouri et al. (2019) showed that the physical properties of the soil do not change in NT systems after 2 years of implantation because few changes occur in the soil in this period.
The intercropping systems used in 2015 were not significantly different from each other at $0-0.10$ and 0.10 $0.20 \mathrm{~m}$ soil depth (Table 4). The soils in WI, PM, UM, and UR were classified as very friable, whereas those in the other treatments were classified as mechanically unstable at $0-0.10 \mathrm{~m}$. At $0.10-0.20 \mathrm{~m}$ soil depth, only the soils in UR and PM were classified as very friable, and the other soils were classified as mechanically unstable according to the classification proposed by Imhoff et al. (2002). High friability values indicate that larger aggregates have lower 
TS values than smaller aggregates, which explains the formation of easily-fractured aggregates when the soil is subjected to tillage, as in the case of treatment WI at 0.10 $0.20 \mathrm{~m}$ soil depth, which presented low resistance but high friability. The highest TS and lowest friability were obtained in treatments UR and PM at $0.10-0.20 \mathrm{~m}$ soil depth and can be justified by the absence of soil mobilization, which preserved the structural quality and bonding of the aggregates.

Aggregate moisture content varied from 0.016 to $0.029 \mathrm{~kg} \mathrm{~kg}^{-1}$ at $0-0.10 \mathrm{~m}$ soil depth and was not significantly different among treatments. However, moisture content was significantly different among treatments at $0.10-0.20 \mathrm{~m}$ soil depth, varying from 0.015 to $0.018 \mathrm{~kg} \mathrm{~kg}$. Notwithstanding, this amplitude of variation was small and did not affect TS measurements.

TS values at $0-0.10$ and $0.10-0.20 \mathrm{~m}$ soil depth in 2016 are shown in Table 5. TS values among treatments were not significantly different at $0-0.10 \mathrm{~m}$ but were significantly different at $0.10-0.20 \mathrm{~m}$. In this analysis, aggregates presented morphological changes and difficulty in positioning for rupture force application, which may justify variability in TS measures.

No significant differences were found for friability at both $0-0.10$ and $0.10-0.20 \mathrm{~m}$ soil depth, among treatments (Table 4).

TABLE 4. Mean values of the tensile strength (TS), friability (F), and moisture content (M) of soil aggregates at $0-0.10$ and 0.10-0.20 m soil depth in the intercropping system of maize with forage grasses in Rondonópolis, Mato Grosso, Brazil, 2016.

\begin{tabular}{|c|c|c|c|c|c|c|}
\hline \multirow{2}{*}{ Treatment } & \multicolumn{3}{|c|}{ 0-0.10 m } & \multicolumn{3}{|c|}{$0.10-0.20 \mathrm{~m}$} \\
\hline & TS & $\mathbf{F}$ & $\mathbf{M}$ & TS & $\mathbf{F}$ & $\mathbf{M}$ \\
\hline P. maximum cv Tanzânia (PT) & $78.48 \mathrm{a}$ & $0.64 \mathrm{a}$ & $0.020 \mathrm{a}$ & $104.9 \mathrm{ab}$ & $0.93 \mathrm{a}$ & $0.018 \mathrm{a}$ \\
\hline Maize without intercropping (WI) & $78.44 \mathrm{a}$ & $0.63 \mathrm{a}$ & $0.016 \mathrm{a}$ & $71.29 \mathrm{~b}$ & $0.87 \mathrm{a}$ & $0.015 \mathrm{c}$ \\
\hline U. humidicola $(\mathrm{UH})$ & $92.84 \mathrm{a}$ & $0.75 \mathrm{a}$ & $0.018 \mathrm{a}$ & $127.04 \mathrm{a}$ & $0.85 \mathrm{a}$ & $0.016 \mathrm{abc}$ \\
\hline P. maximum cv Mombaça (PM) & $76.49 \mathrm{a}$ & $0.89 \mathrm{a}$ & $0.029 \mathrm{a}$ & $79.53 \mathrm{~b}$ & $0.83 \mathrm{a}$ & $0.015 \mathrm{bc}$ \\
\hline U. brizantha cv. Marandú (UM) & $79.40 \mathrm{a}$ & $0.84 \mathrm{a}$ & $0.019 \mathrm{a}$ & $77.02 \mathrm{~b}$ & $0.96 \mathrm{a}$ & $0.016 \mathrm{abc}$ \\
\hline U. decumbens (UD) & $84.40 \mathrm{a}$ & $0.66 \mathrm{a}$ & $0.020 \mathrm{a}$ & $100.10 \mathrm{ab}$ & $0.82 \mathrm{a}$ & $0.016 \mathrm{abc}$ \\
\hline U. ruziziensis (UR) & $97.95 \mathrm{a}$ & $0.72 \mathrm{a}$ & $0.022 \mathrm{a}$ & $99.76 \mathrm{ab}$ & $0.77 \mathrm{a}$ & $0.017 \mathrm{ab}$ \\
\hline MSD & 25.41 & 0.33 & 0.018 & 40.86 & 0.29 & 0.003 \\
\hline $\mathrm{CV}$ & 28.22 & 41.2 & 81.56 & 43.29 & 30.42 & 17.8 \\
\hline
\end{tabular}

Means followed by the same lower-case letters compare the treatments at 0.0-0.10 $\mathrm{m}$ and $0.10-0.20 \mathrm{~m}$ soil depth and they do not differ from each other by the Tukey's test at 5\% probability. MSD, minimum significant difference; $\mathrm{CV}$, coefficient of variation.

Tormena et al. (2008b) observed that soil structure under NT was affected by climatic conditions and the cultivated crops. Therefore, the forage grasses used in the intercropping system were fundamental for soil structuring. The root system of these plants may have affected TS and friability, providing favorable soil structure for crop development.

Jakšík et al. (2015) found that the ASI was influenced by OM content and the latter was the main cementing agent of soil aggregates. Tormena et al. (2008b) reported that the increase in OM content in the soil increased the porosity of aggregates, reducing the number of bonds between the particles and consequently reducing TS. This result may explain the fact that TS values were lower at $0-0.10 \mathrm{~m}$ when compared to $0.10-0.20 \mathrm{~m}$ soil depth.

The mean TS values found by Reis et al. (2014) in a coal mining area were like those found in the present study, corresponding to $74.34 \mathrm{kPa}$ and $90.33 \mathrm{kPa}$ at 0.00 0.05 and $0.05-0.15 \mathrm{~m}$ soil depth, respectively. Friability values in our study were like those found by these authors, ranging from 0.51 to 0.74 at $0.0-0.05 \mathrm{~m}$ and 0.53 to 0.77 at $0.05-0.15 \mathrm{~m}$ soil depth.

\section{CONCLUSIONS}

Maize intercropped with forage grass improved soil structure and aggregation by increasing both aggregate stability and tensile strength.
Aggregate stability was more sensitive in detecting the effects of an intercropping system than was tensile strength and soil friability.

Maize intercropped with Urochloa ruziziensis improved soil aggregation to a greater extent than did those with other forage grasses.

Soil structure at $0.10-0.20 \mathrm{~m}$ depth was the most affected by the intercropping system.

Maize without intercropping was not a feasible crop option for the Cerrado region because of its high risks of soil structure degradation.

\section{ACKNOWLEDGMENTS}

We are grateful to the Coordination for the Improvement of Higher Education Personnel (Coordenação de Aperfeiçoamento de Pessoal de Nível Superior-CAPES) for providing scholarship; to the National Council for Scientific and Technological Development (Conselho Nacional de Desenvolvimento Científico e Tecnológico-CNPq) (Process 442607/2014-8) and the Sustainable Agriculture Foundation (Fundação de Agricultura Sustentável-Agrisus) (Project No. 1314/14) for research funding.

\section{REFERENCES}

Araújo AL, Oliveira RT, Ferreira TO, Romero RE, Oliveira TS (2013) Evaluation of soil structure using participatory methods in the semiarid region of Brazil. Revista Ciência Agronômica 44(3):411-418. 
Blanco-Canqui H, Ruis SJ (2018) No-tillage and soil physical environment. Geoderma 326:164-200.

Brandão ED, Silva IF (2012) Formação e estabilização de agregados pelo sistema radicular de braquiária em um Nitossolo Vermelho. Ciência Rural 42:1193-1199.

Castro Filho C, Lourenço AF, Guimarães ME, Fonseca ICB (2002) Aggregate stability under different soil management systems in a red latosol in the state of Parana, Brazil. Soil and Tillage Research 65(1):45-51.

Ceccon G, Concenço G (2014) Produtividade de massa e dessecação de forrageiras perenes para integração lavourapecuária. Planta Daninha 32:326-326.

Dexter AR, Kroesbergen B (1985) Methodology for determination of tensile strength of soil aggregates. Journal of Agricultural Engineering Research 31:139-147.

Demenois J, Carriconde F, Rey F, Stokes A (2017) Tropical plant communities modify soil aggregate stability along a successional vegetation gradient on a Ferralsol. Ecological Engineering 109:161-168.

Embrapa - Centro Nacional de Pesquisa de Solos (2017) Manual de métodos de análise de solo. Embrapa, CNPS, $573 p$.

Embrapa - Empresa Brasileira de Pesquisa Agropecuária (2018) Sistema brasileiro de classificação de solos. Embrapa Solos, 356p.

Ferreira AO, Sá JCM, Lal R, Tivet F, Clever B, Inagaki TM, Gonçalves DRP, Romaniw J (2018)

Macroaggregation and soil organic carbon restoration in a highly weathered Brazilian Oxisol after two decades under no-till. Science of the Total Environment 621:1559-1567.

Garcia CMP, Andreotti M, Teixeira Filho MCM, Lopes KSM, Buzetti S (2014) Decomposição da palhada de forrageiras em função da adubação nitrogenada após o consórcio com milho e produtividade da soja em sucessão. Bragantia 73(2)-143-152.

Grossman RB, Reinsch TG (2002) Bulk density and linear extensibility. In: Dane JH, Topp C (eds.) Methods of soil analysis: Physical methods. Soil Science Society of America 4:201-228.

Imhoff S, Silva AP, Dexter AR (2002) Factors contributing to the tensile strength and friability of oxisols. Soil Science Society of America Journal 66:1656-1661.

Jakšík O, Kodešová R, Kubiš A, Stehlíková I, Drábek O, Kapička A (2015) Soil aggregate stability within morphologically diverse areas. Catena 127:287-299.

Lemaire G, Franzluebbers A, Carvalho PCF, Dedieu B (2014) Integrated crop-livestock systems: Strategies to achieve synergy between agricultural production and environmental quality. Agriculture, Ecosystems and Environment 190:4-8.

Nouri A, Lee J, Yin X, Saxton AM, Tyler DD, Sykes VR, Arelli P (2019) Crop species in no-tillage summer crop rotations affect soil quality and yield in an Alfisol. Geoderma 345:51-62.
Pacheco LP, São Miguel ASDC, Silva RG, Souza ED, Petter FA, Kappes C (2017) Produção de fitomassa em sistemas de produção de soja em sucessão a culturas semeadas em safrinha. Pesquisa Agropecuaria Brasileira 52:582-591.

Pereira MG, Loss A, Beutler SJ, Torres JLR (2010) Carbono, matéria orgânica leve e fósforo remanescente em diferentes sistemas de manejo do solo. Pesquisa Agropecuária Brasileira 45:508-514.

Pittelkow CM, Liang X, Linquist BA, Van Groenigen KJ, Lee J, Lundy ME, Van Gestel N, Six J, Venterea RT, Van Kessel C (2014) Productivity limits and potencials of the principles conservation agriculture. Nature 0:1-6.

Raij BV, Cantarella H, Quaggio JA, Furlani AMC (1997) Recomendações de adubação e calagem para o Estado de São Paulo. Campinas, Fundação IAC, 285p.

Reis DR, Lima CL, Pauletto EA, Pinto LFS, Garcia GF (2014) Resistência tênsil de agregados e friabilidade de um solo construído em área de mineração de carvão em Candiota RS. Revista Brasileira de Ciência do Solo 38(2):669-678.

Santos GG, Silveira PM, Marchão RL, Petter FA, Becquer T (2012) Atributos químicos e estabilidade de agregados sob diferentes culturas de cobertura em Latossolo do cerrado. Revista Brasileira de Engenharia Agrícola e Ambiental 16(11):1171-1178.

SAS Institute (2002) SAS: user's guide statistics. Cary, SAS Institute, $9^{\text {th }}$ ed. $943 \mathrm{p}$.

Silva TP, Nunes MCM, Lima CLR, Paiva RB, Barbosa LS, Fischer LO (2018) Qualidade estrutural de um Argissolo Vermelho-Amarelo sob diferentes usos no bioma pampa no sul do Brasil. Revista Brasileira de Agropecuária Sustentável 8(2):115-123.

Silva DV, Pereira, GAM, Freitas MAM, Silva AA, Sediyama T, Silva GS, Ferreira LR, Cecon PR (2015) Produtividade e teor de nutrientes do milho em consórcio com braquiária. Ciência Rural, Santa Maria 45(8):1394-1400.

Tormena CA, Araújo MA, Fidalski J, Imhoff S, Silva AP (2008a) Quantificação da resistência tênsil e da friabilidade de um Latossolo Vermelho distroférrico sob plantio direto. Revista Brasileira de Ciência do Solo 32(3):943-952.

Tormena CA, Fidalski J, Rossi Junior W (2008b) Resistência tênsil e friabilidade de um Latossolo sob diferentes sistemas de uso. Revista Brasileira de Ciência do Solo 32(1):33-42.

Watts C, Dexter AR (1998) Soil friability: theory, measurement and the effects of management and organic carbon content. European Journal of Soil Science 49:73-84.

Wendling B, Vinhal-Freitas IC, Oliveira RC, Babata MM, Borges EM (2012) Densidade, agregação e porosidade do solo em áreas de conversão do cerrado em floresta de pinus, pastagem e plantio direto. Bioscience Journal (28):256-265. 